\title{
A murC gene in Porphyromonas gingivalis 381
}

\author{
Toshihiro Ansai, ${ }^{1}$ Yoshihisa Yamashita, ${ }^{2}$ Shuji Awano, ${ }^{1}$ Yukie Shibata, ${ }^{2}$ \\ Masaaki Wachi, ${ }^{3}$ Kazuo Nagai ${ }^{3}$ and Tadamichi Takehara ${ }^{1}$
}

Author for correspondence: Toshihiro Ansai. Fax: +81935917736.

\footnotetext{
1 Department of Preventive Dentistry, Kyushu Dental College, Kitakyushu 803, Japan

2 Department of Preventive Dentistry, Kyushu University Faculty of Dentistry, Fukuoka 8/2, Japan

3 Department of Bioengineering, Tokyo Institute of Technology, Yokohama 226, Japan
}

\begin{abstract}
The gene encoding a 51 kDa polypeptide of Porphyromonas gingivalis 381 was isolated by immunoblotting using an antiserum raised against $P$. gingivalis alkaline phosphatase. DNA sequence analysis of a $2.5 \mathrm{~kb}$ DNA fragment containing a gene encoding the 51 kDa protein revealed one complete and two incomplete ORFs. Database searches using the FASTA program revealed significant homology between the P. gingivalis 51 kDa protein and the MurC protein of Escherichia coli, which functions in peptidoglycan synthesis. The cloned $51 \mathrm{kDa}$ protein encoded a functional product that complemented an E. coli murC mutant. Moreover, the ORF just upstream of murC coded for a protein that was $31 \%$ homologous with the E. coli MurG protein. The ORF just downstream of murc coded for a protein that was $17 \%$ homologous with the Streptococcus pneumoniae penicillin-binding protein 2B (PBP2B), which functions in peptidoglycan synthesis and is responsible for antibiotic resistance. These results suggest that $\boldsymbol{P}$. gingivalis contains a homologue of the E. coli peptidoglycan synthesis gene murC and indicate the possibility of a cluster of genes responsible for cell division and cell growth, as in the $E$. coli mra region.
\end{abstract}

Keywords: Porphyromonas gingivalis, murC, peptidoglycan synthesis, alkaline phosphatase

\section{INTRODUCTION}

Porphyromonas gingivalis, a Gram-negative, anaerobic, rodshaped bacterium, has been isolated from lesions of advanced adult periodontitis (Slots, 1977; Tanner et al., 1979) and implicated as a periodontal pathogen. The detailed pathogenic mechanism of $P$.gingivalis infections is not yet known. This organism produces a variety of potential virulence factors, including alkaline phosphatase (ALPase) (Slot \& Genco, 1984). A previous study showed that ALPase in the cell-associated form of $P$. gingivalis strains exists in the periplasmic space and is released into the culture medium (Minhas \& Greenman, 1989). We have purified the ALPase of $P$. gingivalis 381 to homogeneity, characterized it and raised a polyclonal antibody against it (Yamashita et al., 1990).

During attempts to clone the ALPase gene, we discovered a cluster of genes which appear to be involved in peptidoglycan synthesis. To our knowledge, nothing is

Abbreviations: ALPase, alkaline phosphatase; MurNAc, $\mathrm{N}$-acetylmuramic acid; PBP, penicillin-binding protein.

The GenBank accession number for the nucleotide sequence reported in this paper is $D 28916$. known about the cell wall synthetic machinery in oral bacteria. No genetic study of the enzymes for peptidoglycan synthesis of an oral bacterium has been reported. Here, we report the complete sequence of the $P$. gingivalis murC gene.

\section{METHODS}

Bacterial strain and plasmids. $P$. gingivalis strain 381 was grown anaerobically $\left[5 \%(\mathrm{v} / \mathrm{v}) \mathrm{CO}_{2}, 10 \%(\mathrm{v} / \mathrm{v}) \mathrm{H}_{2}, 85 \%(\mathrm{v} / \mathrm{v}) \mathrm{N}_{2}\right]$ at $37^{\circ} \mathrm{C}$ for $2 \mathrm{~d}$ in brain heart infusion broth (Difco) supplemented with yeast extract $(0.5 \%)$, haemin $\left(5 \mu \mathrm{g} \mathrm{m} l^{-1}\right)$ and menadione $\left(0.5 \mu \mathrm{g} \mathrm{m}^{-1}\right)$. Escherichia coli JM109 [rec A1 sup E44 end A1 bsd 17 gyr $A 96$ rel $A 1$ thiD $\triangle($ lac-pro $A B)\left(\mathrm{F}^{\prime}\right.$ traD 36 pro $A B^{+}$lacl lac $Z$ M15)] was used as the host strain for pBluescript II SK(+) and $\mathrm{KS}(+)$ sub-clones. E. coli strains were grown aerobically in LB broth at $30^{\circ} \mathrm{C}$ with shaking $(200$ r.p.m.). The selective medium contained $50 \mu \mathrm{g}$ ampicillin $\mathrm{ml}^{-1}$. The E. coli murC mutant, ST $222\left(\mathrm{~F}^{-}\right.$thr trp bis thy thi lac gal xyl mtl str $A$ azi) (Miyakawa et al., 1972) was used for complementation tests. This strain was grown in modified Lennox broth containing $20 \mathrm{mg}$ thymine $\mathrm{l}^{-1}$, as described by Ishino et al. (1989).

Preparation and screening of gene library. Chromosomal DNA was isolated from $P$. gingivalis by a modification of the method of Marmur (1961). Briefly, bacterial cells were grown to late exponential phase were lysed in $1.0 \%(\mathrm{w} / \mathrm{v})$ SDS containing 
$50 \mathrm{mM} \mathrm{NaCl}, 50 \mathrm{mM}$ Tris/ $\mathrm{HCl}$ and $100 \mathrm{mM}$ EDTA (pH 7.5). RNA and protein were removed by successive treatment with RNase $A\left(1 \mu \mathrm{g} \mathrm{ml}^{-1}\right)$ and pronase $\left(0.5 \mathrm{mg} \mathrm{m}^{-1}\right)$, and then the high-molecular-mass DNA was further purified by repeated phenol extraction. Chromosomal DNA of $P$. gingivalis 381 was partially digested with Sau3AI and size-fractionated on a 5-20\% (w/v) sucrose gradient in $1 \mathrm{M} \mathrm{NaCl} / 20 \mathrm{mM}$ Tris $(\mathrm{pH} 8.0) / 5$ $\mathrm{mM}$ EDTA by centrifugation at $100000 \mathrm{~g}$ for $21 \mathrm{~h}$ at $4{ }^{\circ} \mathrm{C}$. DNA in the range 5-10 kb was ligated to pBluescript II SK(+) which had been cut with Bam HI and treated with bacterial alkaline phosphatase (Takara Shuzo). The ligated DNA was transformed into competent E. coli JM109 cells by electroporation (E. coli Pulser; Bio-Rad), and the colonies selected by plating on LB agar plates containing $50 \mu \mathrm{g}$ ampicillin $\mathrm{ml}^{-1}$. A single bacterial colony was grown in $3 \mathrm{ml}$ of LB broth containing $50 \mu \mathrm{g}$ ampicillin $\mathrm{ml}^{-1}$ until the $\mathrm{OD}_{550}$ reached $0 \cdot 5$. IPTG was then added to a final concentration of $0.4 \mathrm{mM}$, and the cultures were incubated for an additional $3 \mathrm{~h}$ to induce protein synthesis. Restriction endonucleases (Takara Shuzo) were used as recommended by the suppliers.

Antibody preparation. Specific polyclonal antibodies against purified $P$. gingivalis ALPase were raised in a rabbit as previously described (Yamashita et al., 1990). The IgG fraction was purified using an Affi-gel protein A MAPS-II kit (Bio-Rad) according to the method of Yamashita et al. (1990). The antibodies were used to identify immunoreactive clones in colony blotting and to perform immunoblot analysis. The antiserum was absorbed with sonicated E. coli JM109 cells containing the vector grown in LB broth (Maniatis et al., 1982).

Colony blotting. Transformed bacterial colonies were transferred directly from agar plates onto dry nitrocellulose filters and lysed as described by Meyer et al. (1982). Blotting was done according to the methods of Hawkes et al. (1982).

Immunoblot analysis. Antigens were electrophoretically transferred onto a nitrocellulose filter immediately after SDS-PAGE by the method of Laemmli (1970). Kaleidoscope-prestained standards (Bio-Rad) were run on each gel for estimation of molecular size. Nitrocellulose sheets were blocked in TBS $(0.05 \mathrm{M}$ Tris $/ 0.2 \mathrm{M} \mathrm{NaCl}, \mathrm{pH} 7 \cdot 5)$ containing $3 \%$ gelatin for $1 \mathrm{~h}$ at room temperature and then incubated for $2 \mathrm{~h}$ at room temperature with rabbit antiserum against purified $P$. gingivalis ALPase diluted $1: 500$ in TTBS (TBS containing $0.05 \%$ Tween 20) containing $1 \%$ gelatin. The nitrocellulose sheets were incubated for an additional $1 \mathrm{~h}$ with peroxidase-conjugated goat anti-rabbit IgG (Bio-Rad) diluted 1:3000 in TTBS containing $1 \%$ gelatin. Bound IgG was visualized in TBS containing $0.05 \%$ 1-chloro-4-naphthol, $16 \%$ (v/v) methanol, and 0.015\% hydrogen peroxide.

Purification of recombinant protein. Cells from a 1 l overnight culture of transformed $E$. coli were harvested by centrifuging at $10000 \mathrm{~g}$ for $20 \mathrm{~min}$. The cells were washed twice with TBS buffer, suspended in $50 \mathrm{mM}$ Tris/ $\mathrm{HCl}, \mathrm{pH} 8 \cdot 2$, and disrupted by sonication. The resulting sonicate was centrifuged at $100000 \mathrm{~g}$ for $40 \mathrm{~min}$ and the supernatant fraction was collected as the crude enzyme extract. The crude enzyme extract was applied to a DEAE-cellulose column $(6 \times 20 \mathrm{~cm})$ that had been equilibrated with $50 \mathrm{mM}$ Tris/HCl buffer, $\mathrm{pH} 8 \cdot 2$. The column was washed with the equilibration buffer until no protein was detected in the effluent by $A_{280}$, and then the column was eluted with a linear $0-1.0 \mathrm{M} \mathrm{NaCl}$ gradient in $1 \mathrm{l}$ of the same buffer. Fractions containing the $51 \mathrm{kDa}$ protein were confirmed by the dot-blotting method, and were then pooled and concentrated by filtration through a Centricon-30 ultrafilter (Amicon). The concentrated solution was applied to a hydroxyapatite column
$(1.6 \times 16 \mathrm{~cm})$ that was equilibrated with $5 \mathrm{mM}$ potassium phosphate buffer, $\mathrm{pH} 8.2$. The column was eluted with a linear 5-200 mM potassium phosphate buffer gradient. Fractions containing the $51 \mathrm{kDa}$ protein were confirmed by the dotblotting method with immunodetection and were pooled and concentrated by ultrafiltration. The enzyme was next applied to a Superdex 200 HR 10/30 gel filtration column (Pharmacia). Fractions containing the $51 \mathrm{kDa}$ protein were confirmed by the dot-blotting method, pooled and concentrated by ultrafiltration, and used as the purified enzyme.

DNA manipulations. The isolation of plasmid DNA, endonuclease restriction and ligation were carried out as previously described (Yamashita et al., 1993). DNA fragments were routinely analysed on 0.7 or $2.0 \%$ (w/v) agarose gels (SeaKem GTG agarose, FMC BioProducts) as described by Maniatis $e t a l$. (1982). Southern blot analysis was performed as previously described (Yamashita et al., 1993) using digoxigenin-labelled probes according to the instructions of the suppliers (Boehringer Mannheim).

DNA sequence analysis. The plasmids pBluescript II KS(+) and $\mathrm{SK}(+)$ (Stratagene) were used as vectors in preparation of unidirectional deletion plasmids for sequencing. Unidirectional deletion subclones were prepared by exonuclease III/mung bean nuclease digestion with appropriate sets of restriction enzymes. A single-stranded template DNA was isolated. The nucleotide sequences were determined using the dideoxy method (Sanger et al., 1977) with a fluorescent primer cycle sequencing kit (Applied Biosystems) and a model 381 automated sequencer (Applied Biosystems). Approximately 300 bases were read from each sample. The nucleotide sequences were analysed with the computer software package 'DNA strider v.1.2' (Marck, 1988). The Protein Identification Resource and the Swiss Protein Source were searched for proteins that share homology with the deduced amino acid sequence of the $51 \mathrm{kDa}$ protein of $P$. gingivalis 381 using the FASTA program (Pearson \& Lipman, 1988).

\section{RESULTS AND DISCUSSION}

\section{Cloning of the gene encoding a $51 \mathrm{kDa}$ protein and immunoblot analysis}

An initial screening was performed by the colony blotting method using a polyclonal antibody raised against the purified ALPase of $P$. gingivalis strain 381. More than

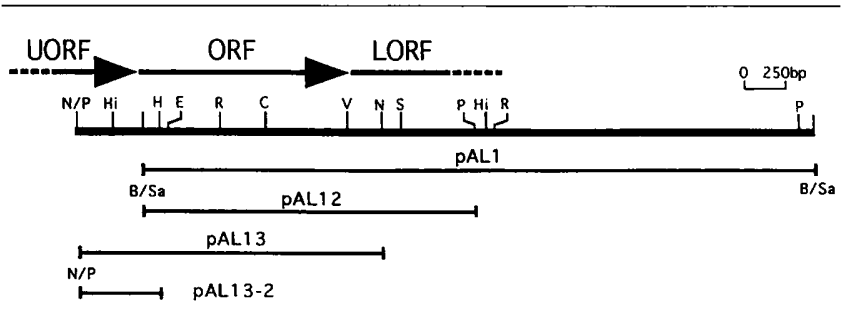

Fig. 1. Restriction endonuclease map of the $P$. gingivalis DNA fragment in pAL1 and PAL13, and in subclones PAL12 and pAL13-2. All clones are derivatives of pBluescript II SK(+). These clones are aligned beneath the restriction sites used for construction. Restriction enzymes: B, BamHI; C, Ncol; E, Eagl; H, HindlII; Hi, Hincll; N, Nsil; P, Pstl; R, EcoRI; S, Sacll; Sa, Sau3Al, $\mathrm{V}$, ECORV. Arrows indicate direction of transcription. 
(a)

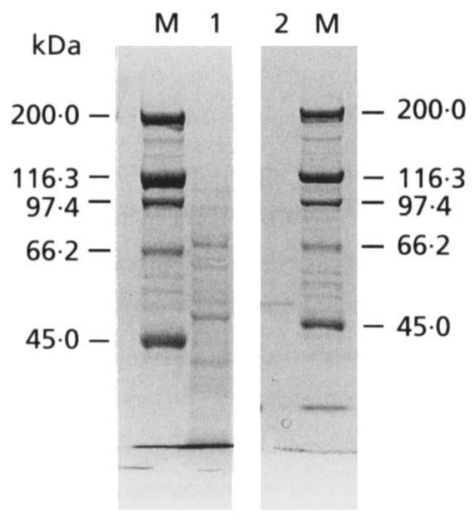

(b)

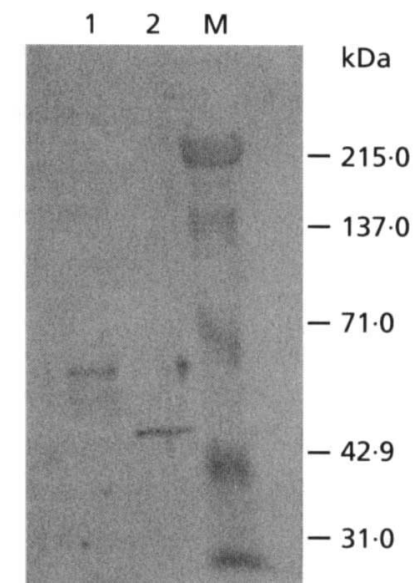

Fig. 2. (a) SDS-PAGE analysis of proteins from recombinant $E$. coli. Lanes: 1, crude extract of $E$. coli JM109 harbouring PAL13 (induced with IPTG); 2, purified $51 \mathrm{kDa}$ protein of $E$. coli JM109 harbouring PAL13; $M$, prestained molecular mass standards. Ten microlitres of sample was loaded in each lane. (b) Immunoblot analysis of the expressed $51 \mathrm{kDa}$ protein cross-reactive with anti- $P$. gingivalis ALPase antiserum. Lanes: 1, purified ALPase from $P$. gingivalis 381 (molecular mass $61 \mathrm{kDa}$ ) (Yamashita et al., 1990); 2, purified $51 \mathrm{kDa}$ protein from $E$. coli JM109 harbouring PAL13; M, prestained molecular mass standards. Ten microlitres of sample was loaded in each lane.
10000 transformants were screened but only two clones reacted strongly with the $P$. gingivalis ALPase polyclonal antibody. These clones were designated pAL1 and pAL2. Immunoblot analysis showed that pAL1 and pAL2 expressed proteins of approximately 47 and $40 \mathrm{kDa}$, respectively. These clones, which exhibited no ALPase activity, did not react at all with preimmunization sera. Initially, clone pAL1, which reacted more strongly with antibody, was selected for further study (Fig. 1). Details of the second clone, pAL2, will be reported elsewhere. Subclone pAL12, which was constructed by deleting the PstI-EcoRI (one site in the polylinker) DNA fragment, still expressed the $47 \mathrm{kDa}$ protein. Nucleotide sequence analysis of the Bam HI/Sau3AI-Pst Iragment in subclone pAL12 revealed a 1278 bp incomplete ORF (bases 4321709 in Fig. 3) with a calculated molecular mass of 47394 $\mathrm{Da}$. These results suggested that an in-frame gene fusion under lac control had been fortuitously constructed and that this sequence was missing the $5^{\prime}$ end of the gene. The $1.5 \mathrm{~kb} \mathrm{BamHI} /$ Sau3AI-SacII fragment within pAL12 was therefore used to synthesize a digoxigenin-labelled probe. This probe was used to identify complete-ORF-containing fragments in genomic digestions of $P$. gingivalis. After the second round of screening by colony blotting, a transformant containing a $1.9 \mathrm{~kb} N s i \mathrm{I} /$ sstI-NsiI fragment was isolated and designated pAL13 (Fig. 1).

\section{pAL13 encodes a $51 \mathrm{kDa}$ protein}

Fig. 2(a) shows the SDS-PAGE analysis of the purified $51 \mathrm{kDa}$ protein from recombinant $E$. coli harbouring pAL13 induced with IPTG. Fig. 2(b) shows the immunoblot analysis using the polyclonal antibody against purified $P$. gingivalis ALPase. Immunoblotting of the purified protein from transformant pAL13 separated by SDSPAGE consistently identified a protein band of molecular mass approximately $51 \mathrm{kDa}$ reacting with the anti-ALPase serum. A corresponding band was not present in the extract of E. coli JM109 containing pBluescript II SK $(+)$. These findings suggest either that the $51 \mathrm{kDa}$ protein and $61 \mathrm{kDa}$ ALPase share immunologically similar domains and contain common antigenic epitopes, or that the preparation of ALPase used to raise antiserum contained some of the $51 \mathrm{kDa}$ protein. We cannot at present distinguish between these possibilities.

\section{Nucleotide sequence and identification of ORFs}

The PstI-XbaI (vector) fragment of pAL12 was recloned into pBluescript II KS(+) to construct pAL12 KS, which was used to prepare unidirectional deletion plasmids for sequencing in a reverse direction. A series of nested deletion plasmids were generated from both the $\mathrm{SalI}$ and EagI sites in pAL12 and pAL12KS, respectively. For sequencing of approximately $500 \mathrm{bp}$ downstream from the NsiI/PstI site, the synthetic primers pAL13-2 and pAL13KS were used (Fig. 1). Plasmid pAL13KS was constructed by recloning of the $X b a \mathrm{I}$ (vector)-SalI (vector) fragment into pBluescript II KS $(+)$. Since the coding region was sequenced on both strands by using overlapping fragments, we had no indication of a sequencing error. This sequence contains one complete and two incomplete ORFs (Fig. 3). A long ORF was identified which contained $1371 \mathrm{bp}$ coding for a putative protein with 457 amino acids (with a calculated molecular mass of $50801 \mathrm{Da}$ ). A potential RBS, ACGAGAA, was identified as starting at base position 320 . Two additional ORFs were identified downstream (LORF, initiated at base position 1727) and upstream (UORF) from ORF. A potential RBS for LORF, AGAAGGT, was identified starting at base position 1710, upstream from CTG, the proposed start codon (Stormo, 1986). The ACGAGAA and the AGAAGGT sequences showed homology to the $3^{\prime}$ end of Bacteroides fragilis 16S rRNA. In particular, the latter sequence was identical to the RBS in the fimbrilin gene of $P$. gingivalis 381 (Dickinson et al., 1988).

\section{Amino acid sequence comparison of ORFs}

The deduced amino acid sequences of the ORFs were compared with sequences of other proteins in the European Molecular Biology Laboratory database. As 


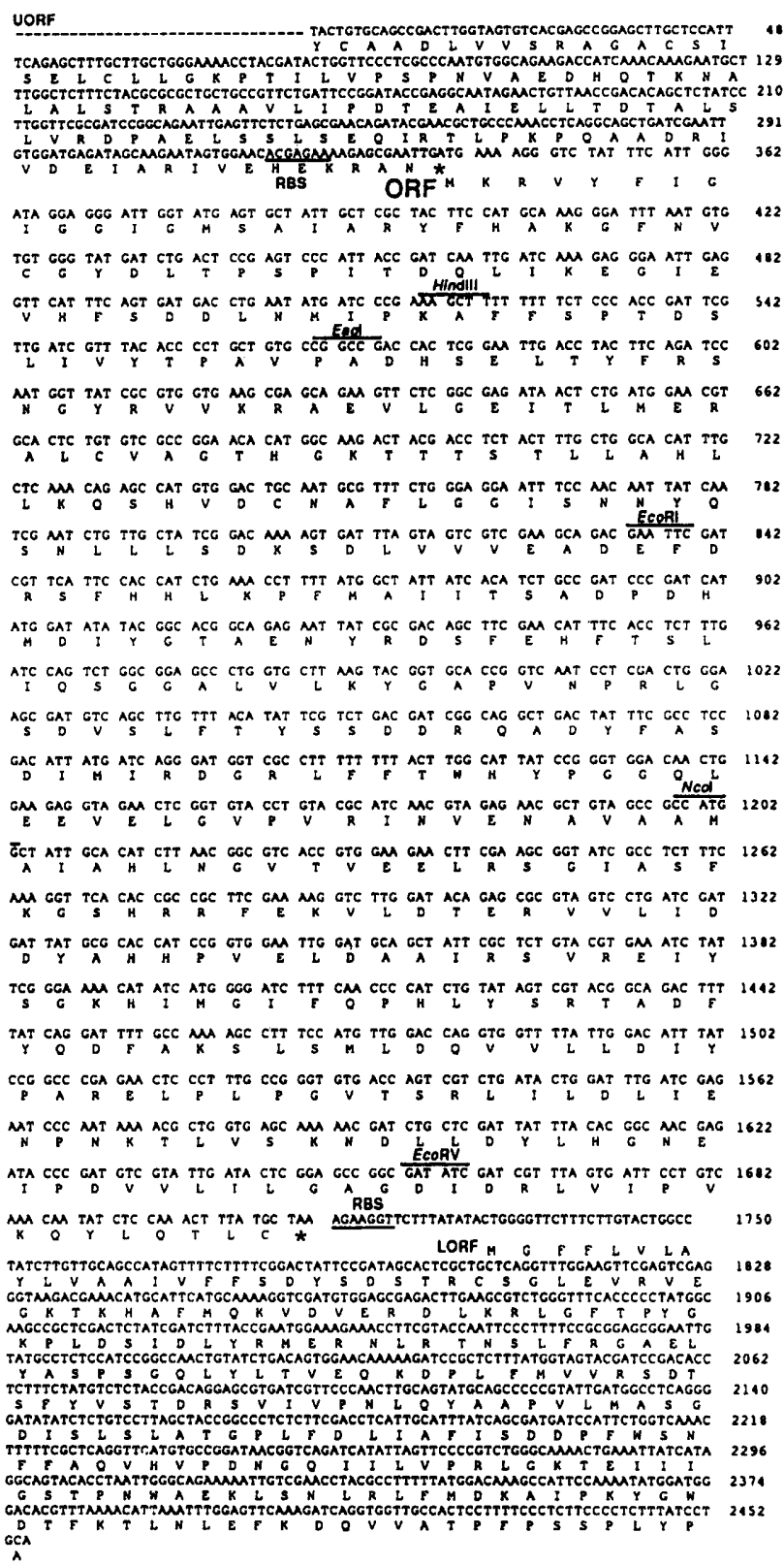

Fig. 3. Nucleotide sequence of the $P$. gingivalis homologue of the $E$. coli murC gene. The complete nucleotide sequence determined is presented. The deduced amino acid sequences of the three ORFs located in this region, UORF (bases 1-338), ORF (bases 339-1709) and LORF (bases 1727-2455) are shown. The deduced positions and amino acid sequences of the $P$. gingivalis murC gene product are shown. RBSs are underlined. The translation and termination codons are marked with asterisks. Relevant restriction sites are indicated above their corresponding recognition sequences.

shown in Fig. 4, the ORF gene product exhibited significant homology (31\% identical amino acid residues and $72 \%$ conservative changes) with the $E$. coli MurC protein and included the ATP-binding domain GXXGKT (Ikeda et al., 1990) (positions 114-119 of the ORF). The ORF of murC in E. coli is $1473 \mathrm{bp}$ in length and encodes a peptide of 491 amino acid residues (with a

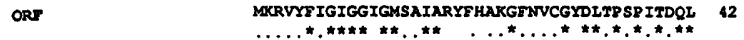

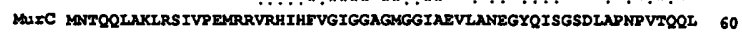

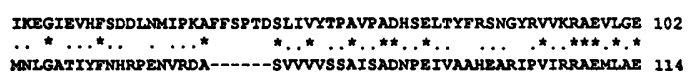

ITLMERALCVAGTHGKTTTSTLLAHLLKQSHVDCNASLGGISNNYQSNLLISDKSDLVVV 162 IARTRRGIAIAGTHGKTTTTANVSSTYAEAGLDPTFVNGGLVKCANGVHARLGH-GRYLIA 173

ENDEFDRSFHHLKPFMAIITSADPDHDIY-GTAENYRDSTEHFTSLIQSGGALVLKYGA 221

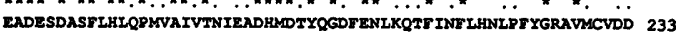

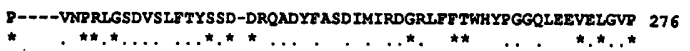
PVIRELLPRVGRTTYYYGSEDADVRVEDY--QQIGPQGH--FTLLRQDKEPMRVTLNAP 289

VRINVENAVAAMATAHLNGVTVEELRSGIASFKGSHRRTE--------KVLD-TERVVLI 327

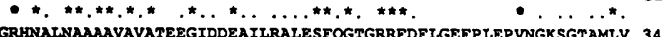

GRHNALNAMAVAVATEEgIDDEAILRALESFQGTGRRD DIGETPLEPVIGKSGIALV 349

DDYAHHPVELDAATRSRETYSGKHIMGIFQPHLYSRTADFYQDTAKSLSMLDQVVILDI 387 DDYGHHPTEVATIKAARAGWPDKNLVMLEQPHRTTRTRDLYDDFANVITQVDTLLMLEV 409

YPARILPLPGVTSR-I--IIDLIENPNXTLVSXNDLLDYLHGNEIPDVVLIL--GAGDID 442

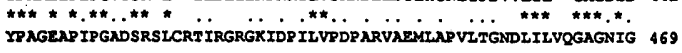

RIVIPVKQYLQTLCE

XINRSLAEIKLKPQTPEEEQHD

Fig. 4. Homology between the deduced amino acid sequence of the ORF gene product and the MurC protein from $E$. coli. Amino acids are numbered on the right. Asterisks and dots indicate identical amino acid residues and conservative changes, respectively.

(a)

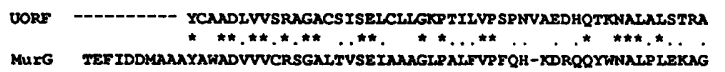

AAVLIPDTE-AIELLTDTALSLVRDPAELSSLSEQIRTLPKPQAADRTVDETARTVEREKRAN AAKIYEQPQLSVDAVANTLAGWSRE--TLLITWERARUASIPDATERVANEVSRVARA

(b)

LORF MGFFLVLAYLVAMTVFFSDYSDSTRCSGLEVRVEGKTKH

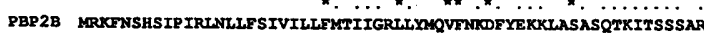

A--F--MQKVDVERDLKR-LOFTPYGKXIDSTDLYRRIERNLRTNSLFRGAEIYASPSGQI GETYDASGKPLVENTLKQVVSFTRSNK-MTATDLKETAKKLLTYVSISSPNL-TERAGDY

YLTVEQKOPLFYVURSDTSFYVSTDRSVIVPNLOYANPVLAASGDISLSL-ATGPLFDII YLADPEIYKKIVEALP SEKRIDSDGNRLSESELYNNAVDSVOTSQLNYTEDEKKEIYLFS

AFISDDPFWSNFFAQVHVPDNGQIILVPRLGKTEIIIGSTRPWNAKLSNLRLF --.--

QLNAVGNEATGTIATDPI-NDSQVAVIASISKEAPGISISTSWDRKVLETSLSSIVGSVS

238

Fig. 5. Homology between the amino acid sequence of the UORF gene product and the $E$. coli MurG protein (a), and between the LORF gene product and PBP2B protein from S. pneumoniae (b). Asterisks and dots indicate identical amino acid residues and conservative changes, respectively.

calculated molecular mass of 53625) (Ikeda et al., 1990). Significant homology (31\% identical amino acid residues and $73 \%$ conservative changes) was also found between the UORF gene product and the E. coli MurG protein, which functions in lipid II biosynthesis (Fig. 5a). Finally, significant similarity ( $17 \%$ identical amino acid residues 
murC $-1 \mathrm{pBSmurC} \Delta \quad$ murC $-1 \mathrm{pBSmurC}+$

(a)

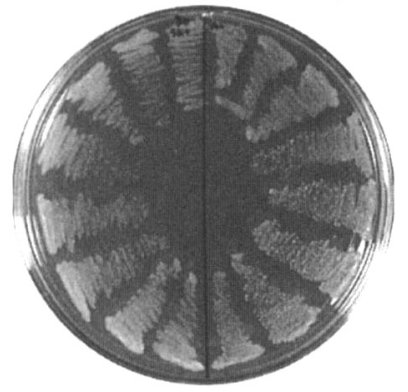

(b)

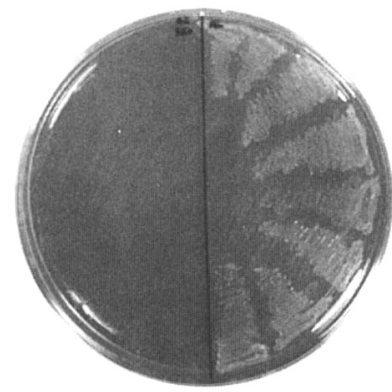

P. gingivalis

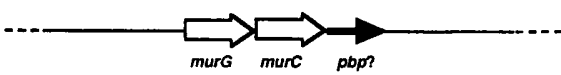

E. coli mra region

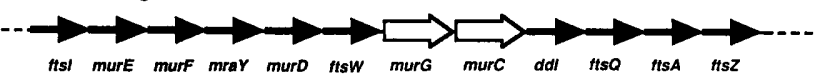

Fig. 7. Comparison of clusters of genes in the mra region of $E$. coli chromosome with the murG-pbp2b region of $P$. gingivalis. Open arrows indicate homologous genes. Lengths and distances are arbitrary.

E. coli is $53 \mathrm{bp}$, but there is no spacing in $P$. gingivalis. The next gene in $E$. coli, $d d l B$ (coding for D-alanine: D-alanine ligase), does not resemble the downstream partial sequence in the cloned $P$. gingivalis fragment.

The $51 \mathrm{kDa}$ protein showed a high degree of homology with the $E$. coli MurC protein, which functions in cell wall peptidoglycan synthesis. The biosynthesis of the bacterial cell wall peptidoglycan is a complex process (Rogers et al., 1980) and UDP-MurNAc: $\mathrm{L}$-alanine ligase (MurC protein) catalyses the first step in the biosynthesis of the cell wall peptidoglycan. The region of about $12 \mathrm{~kb}, m r a$ (murein synthesis cluster a), at $2 \mathrm{~min}$ on the $E$. coli chromosome map, contains genes concerned with peptidoglycan synthesis, which have been shown to be tightly clustered forming an operon (Miyakawa et al., 1972).

These results suggest that $P$. gingivalis contains a homologue of the $E$. coli peptidoglycan synthesis gene mur $C$ and indicate the possibility of a cluster of genes responsible for cell division and cell growth as in the E. coli mra region. It is important that the mur $C$ gene of $P$. gingivalis, a periodontopathic bacterium, is isolated. Peptidoglycans have a number of biological activities in mammalian systems and are known to activate the alternative pathway of complement fixation and cause polyclonal B lymphocyte activation (Hunter, 1984). The inhibition of its biosynthesis has either a bacteriostatic effect or, more often, a bactericidal one. Research on genes responsible for peptidoglycan synthesis may lead to a new therapy for periodontal disease.

In conclusion, we have isolated and sequenced a gene encoding the $P$. gingivalis MurC protein. The MurC protein sequences have been found to be conserved between $E$. coli and $P$. gingivalis and it is suggested that the murC gene and neighbouring cell wall synthesis genes may be clustered. $42{ }^{\circ} \mathrm{C}$. Plasmid pAL13 was a derivative of pBluescript $\mathrm{SK}(+)$ harbouring the entire $P$. gingivalis murC gene. Plasmid pAL13 was able to rescue the $t s$ growth defect for ST 222 (right sector at 30 and $42^{\circ} \mathrm{C}$ ). However, when this strain was transformed with pBluescript II $\mathrm{SK}(+)$, complementation of the $t s$ growth defect was not observed (Fig. 6, compare left sector at 30 and $42^{\circ} \mathrm{C}$ ). These data demonstrate that the $P$. gingivalis gene encodes an active product that confers the $\mathrm{MurC}^{+}$phenotype in E. coli.

Fig. 7 shows the alignments of the genes of the murG$p b p 2 b$ region of $P$. gingivalis and $m r a$ region of $E$. coli. The mur $G$ and murC genes are also adjacent in E. coli, although the spacing between them is different: the spacing in

\section{REFERENCES}

Dickinson, D. P., Kubiniec, M. A., Yoshimura, F. \& Genco, R. J. (1988). Molecular cloning and sequencing of the gene encoding the fimbrial subunit protein of Bacteroides gingivalis. $J$ Bacteriol 170, 1658-1665.

Hawkes, R., Niday, E. \& Gordon, J. (1982). A dot-immunobinding assay for monoclonal and other antibodies. Anal Biochem 119 , 142-147.

Hunter, N. (1984). The interaction of bacterial peptidoglycan with macrophages in chronic inflammation. $J$ Dent Res 63, 427-430. 
Ikeda, M., Wachi, M., Jung, H. K., Ishino, F. \& Matsuhashi, M. (1990). Nucleotide sequence involving murG and murC in the mra gene cluster region of Escherichia coli. Nucleic Acids Res 18, 4014.

Ishino, F., Jung, H. K., Ikeda, M., Doi, M., Wachi, M. \& Matsuhashi, M. (1989). New mutations $f t s-36$, lts-33, and $f t s W$ clustered in the mra region of the Escherichia coli chromosome induce thermosensitive cell growth and division. $J$ Bacteriol 171, 5523-5530.

Laemmli, U. K. (1970). Cleavage of structural proteins during the assembly of the head of bacteriophage T4. Nature 227, 680-685.

Maniatis, T., Fritsch, E. F. \& Sambrook, J. (1982). Molecular Cloning: a Laboratory Manual. Cold Spring Harbor, NY: Cold Spring Harbor Laboratory.

Marck, C. (1988). 'DNA strider' : a 'C' program for the fast analysis of DNA and protein sequences on the Apple Macintosh family of computers. Nucleic Acids Res 16, 1829-1836.

Marmur, J. (1961). A procedure for the isolation of deoxyribonucleic acid from microorganisms. J Mol Biol 3, 208-218.

Meyer, T. F., Mlawer, N. \& So, M. (1982). Pilus expression in Neisseria gonorrboeae involves chromosomal rearrangement. Cell 30 , 45-52.

Minhas, H. \& Greenman, J. (1989). Production of cell-bound and vesicle-associated trypsin-like protease, alkaline phosphatase and $N$-acetyl- $\beta$ glucosaminidase by Bacteroides gingivalis strain W50. $J$ Gen Microbiol 135, 557-564.

Miyakawa, T., Matsuzawa, H., Matsuhashi, M. \& Sugino, Y. (1972). Cell wall peptidoglycan mutants of Escherichia coli K-12: existence of two clusters of genes, $m r a$ and $m r b$, for cell wall peptidoglycan biosynthesis. J Bacteriol 112, 950-958.

Nanninga, N. (1991). Cell division and peptidoglycan assembly in Escherichia coli. Mol Microbiol 5, 791-795.

Pearson, W. G. \& Lipman, D. J. (1988). Improved tools for biological sequence comparison. Proc Natl Acad Sci USA 85, 2444-2448.

Rogers, H. J., Perkins, H. R. \& Ward, J. B. (1980). Biosynthesis of peptidoglycan. In Microbial Cell Walls and Membranes, pp. 239-297. Edited by H. J. Rogers, H. R. Perkins \& J. B. Ward. London: Chapman \& Hall.

Sanger, F., Nicklen, S. \& Coulson, A. R. (1977). DNA sequencing with chain-terminating inhibitors. Proc Natl Acad Sci USA 74, 5463-5467.

Slots, J. (1977). The predominant cultivable microflora of advanced periodontitis. Scand J Dent Res 85, 114-121.

Slots, J. \& Genco, R. J. (1984). Black-pigmented Bacteroides species, Capnocytophaga species, and Actinobacillus actinomycetemcomitans in human periodontal disease: virulence factors in colonization, survival, and tissue destruction. J Dent Res 63, 412-421.

Stormo, G. D. (1986). Translation initiation. In Maximizing Gene Expression, pp. 195-224. Edited by W. Reznikoff \& L. Gold. Boston, MA: Butterworth.

Tanner, A. C. R., Haffer, C., Bratthall G. T., Visconti, R. A. \& Socransky, S. S. (1979). A study of the bacteria associated with advancing periodontitis in man. J Clin Periodontol 6, 278-307.

Waxman, D. J. \& Strominger, J. L. (1983). Penicillin-binding proteins and the mechanism of action of $\beta$-lactam antibiotics. Annu Rev Biocbem 52, 825-869.

Yamashita, Y., Toyoshima, K., Yamazaki, M., Hanada, N., \& Takehara, T. (1990). Purification and characterization of alkaline phosphatase of Bacteroides gingivalis 381. Infect Immun 58, 2882-2887.

Yamashita, Y., Takehara, T. \& Kuramitsu, H. K. (1993). Molecular characterization of a Streptococcus mutans mutant altered in environmental stress responses. $J$ Bacteriol 175, 6220-6228.

Received 4 January 1995; revised 1 May 1995; accepted 5 May 1995. 